\section{Studies published in indexed journals on lawsuits for medicines in Brazil: a systematic review}

\author{
Estudos publicados em periódicos indexados sobre \\ decisões judiciais para acesso a medicamentos no \\ Brasil: uma revisão sistemática
}

\section{Estudios publicados en revistas indexadas acerca de decisiones judiciales para el acceso a los medicamentos en Brasil: una revisión sistemática}

\author{
1 Programa de Pós-graduação \\ em Assistência Farmacêutica \\ Universidade Federal do Rio \\ Grande do Sul, Porto Alegre, \\ Brasil. \\ Correspondence \\ T. A. Amador \\ Programa de Pós-graduação \\ em Assistência Farmacêutica \\ Universidade Federal do Rio \\ Grande do Sul. \\ Av. Ipiranga 2752, sala $602 \mathrm{~A}$, \\ Porto Alegre, RS \\ 90610-000, Brasil. \\ tania.alves@ufrgs.br
}

\begin{abstract}
The aim of this systematic review was to identify and characterize articles in indexed scientific journals with quantitative data surveys on administrative or legal proceedings for access to medicines. The SciELO, LILACS, MEDLINE via PubMed, Embase, and Scopus databases were used. We identified 45 articles, of which 17 were selected. The larger studies, each covering between 2,000 and 2,927 lawsuits, were done in the states of São Paulo, Rio de Janeiro, and Santa Catarina, Brazil. Eleven studies specified the type of legal representation, of which six examined cases with public attorneys and five with private attorneys. Only two studies reported whether the lawsuit was individual or class action, and in both the claims were individual. Since the majority of the medicines requested in the lawsuits were medium to high-cost, the review indicates that lawsuits contributed to the incorporation of these drugs into current pharmaceutical care in Brazil.
\end{abstract}

Judicial Decisions; Pharmaceutical Services; Right to Health
Vanessa Santana Gomes 1

Tânia Alves Amador 1

\section{Resumo}

O objetivo desta revisão sistemática foi identificar e caracterizar artigos disponíveis em periódicos científicos indexados em bases eletrônicas, que realizaram levantamento de dados quantitativo, em processos administrativos ou judiciais, sobre a questão do acesso a medicamentos por meio de ações judiciais. Foram usadas as bases de dados SciELO, LILACS, MEDLINE via PubMed, Embase e Scopus. Identificamos 45 artigos, dos quais foram selecionados 17 artigos. Os estudos com faixa de 2.000 a 2.927 processos foram conduzidos em São Paulo, Rio de Janeiro e Santa Catarina, Brasil. Em 11 estudos foram pesquisadas qual a representação jurídica da ação. Em seis estudos predominaram a representação de advogados públicos e em cinco particulares. Somente dois estudos observaram se a ação era coletiva ou individual, sendo que nas duas pesquisas a prevalência era de ações individuais. Como a maioria dos medicamentos envolvidos nas ações é de médio e alto custo, acredita-se que as demandas judiciais tenham contribuído para incorporação de medicamentos nas ações de assistência farmacêutica atuais.

Decisões Judiciais; Assistência Farmacêutica; Direito à Saúde 


\section{Introduction}

Various segments of Brazilian society have increasingly discussed health-related lawsuits, or the "judicialization" of health care. Health-related lawsuits have drawn extensive media coverage, with frequent newspaper and magazine stories reporting on right-to-health legal claims. The discussion is also high on the agendas of the health sector and the judiciary. Based on Article 196 of the 1988 Federal Constitution, that "Health is the right of all persons and the duty of the State", the number of Brazilians that sue to ensure this right has grown exponentially.

Data from the Brazilian Ministry of Health show that health-related lawsuits have increased year by year. There were 10,486 new lawsuits filed against the federal government in 2009, followed by 11,203 in $2010,12,811$ in 2011, and 13,051 in 20121 . According to government data, most of these lawsuits are for access to medicines 2 .

Due to this growing demand, studies in different states of Brazil have attempted to explain the judicialization phenomenon, identifying the general profile of lawsuits, drawing inferences on the claims, describing the various issues involved, and proposing alternatives to solve the problems.

The current study thus aimed to conduct a systematic review to identify and characterize articles published in indexed scientific journals with quantitative data surveys on administrative or legal proceedings for access to medicines in Brazil.

The government is aware that the majority of the claims are for access to medicines 2 .

Studies on the phenomenon of judicialization have thus been done in various states of Brazil, drawing a profile of the lawsuits, identifying the underlying causes, describing the issues involved, and seeking alternatives to solve problems.

The growing number of lawsuits related to medicines and the number of publications on this issue motivated this systematic review, which aims to identify and characterize studies with surveys on lawsuits related to medicines in Brazil.

\section{Methods}

This descriptive study used the criteria defined by Preferred Reporting Items for Systematic Reviews and Meta-Analyses (PRISMA) ${ }^{3}$.
Eligibility criteria for articles

The following criteria were adopted for the inclusion of articles: (1) surveys of data on administrative claims involving health administrators or lawsuits; (2) claims that involved medicines; (3) studies available in the form of scientific articles; (4) publication in journals that were indexed in the selected databases; and (5) quantitative data surveys. The review excluded studies that were theoretical analyses of the health judicialization phenomenon in general or of access to medicines in particular, as well as proceedings of meetings, monographs, theses, and bulletins and newsletters by health administrators.

\section{Search strategy for the identification} of articles

The articles were identified by searches in the SciELO, LILACS, MEDLINE via PubMed, Embase, and Scopus databases. In addition to use of the single databases, we also used the search interface in the Virtual Health Library (BIREME). Identification of studies began with a broad review in order to identify descriptors that were sufficiently sensitive to locate articles the met the study's objectives. The search strategy was prepared by identifying Health Sciences Descriptors (DeCS) in BIREME in English and Portuguese.

The terms located with this strategy were applied one by one to test their sensitivity, which produced the following combination: "drugs and judicial decisions", "right to health" and "judicial power”, "Unified National Health System (SUS)”, and "pharmaceutical services", "health policy" and "judicialization". These three intersections were applied one by one, since we found that grouping them decreased their search sensitivity. Another finding related to the term "judicialization", which is not a DeCS descriptor or Medical Subject Headings (MeSH) keyword, but has been used in the titles of articles in some Brazilian journals, accepted as a keyword, and has been accepted as a term to locate articles, which led to its inclusion in our search strategy. The search was limited to English and Portuguese. The references of the selected articles were checked manually to identify other articles that met the inclusion criteria but had not been located in the databases. The search was conducted in April and May 2012, and in June 2014 an updated search was done in MEDLINE via PubMed and SciELO.

\section{Literature review methods}

Two researchers independently performed the search and initial screening of article titles, and 
their findings were compared to identify similar results. In case of disagreement, the method was reviewed and the search was repeated. The articles were first selected independently by the two researchers based on the titles, and in case of doubt, by reading the abstracts. The selected articles were transferred to EndNote (Thomson Reuters. http://www.endnote.com/) for storage and management of the references, and duplicates were excluded. In case of disagreement on inclusion or exclusion, a third researcher was consulted. The full texts of articles were retrieved and read by the principal investigator, and in case of doubt on the inclusion or exclusion of a given article, the decision was discussed between the review's authors.

\section{Data extraction}

After selection and complete reading of the articles, a database was created in Excel (Microsoft Corp., USA) to manage the information. The data's reliability and validity were evaluated according to the description of each study's method and generalization in the study's context. No scale was found to evaluate the quality of articles that reported studies on health-related lawsuits, so information from the articles was extracted and analyzed using the checklist from Strengthening the Reporting of Observational Studies in Epidemiology (STROBE) 4. Although the latter is not a quality evaluator, it served as a parameter for finding relevant information in the articles in comparison to the checklist's criteria. The following information was collected and recorded: title, authors, periodical, year, country and language of publication, objectives, methods (design, study subjects, variables, data sources, study size), results, conclusions, and limitations.

\section{Results}

The search in the electronic databases identified 1,023 studies, of which 45 were selected for reading the full text. After a more detailed analysis and applying the exclusion criteria, the number was reduced to 15 articles. When the data were updated in June 2014, five more articles were identified, of which three were excluded because they failed to meet the selection criteria. Thus, 17 articles were finally selected and included (Figure 1). As for adequacy of the information in the articles according to the STROBE criterion of specifying limitations, seven articles did not refer to limitations, and those which did so reported the following principal limitations: small number of lawsuits analyzed (preventing external valida- tion), access to data on patients, and the diseases involved in the claims for medicines.

Of the studies that were analyzed, $43.7 \%$ were published in the years 2010 and 2011 in Brazil (93.7\%). The Brazilian states with the most publications on the issue of lawsuits for medicines were São Paulo (31.2\%) and Rio de Janeiro (25\%). A total of 17,783 lawsuits for medicines were analyzed from 2005 to 2013. The journal with the most articles on health-related lawsuits was $R e$ vista de Saúde Pública (Table 1).

\section{Description of publications, document sources, and legal aspects}

Tables 1 and 2 summarize the overall data in the publications, study characteristics, and sources used in the data collection. The first year of the publications included in the review was 2005, and there was a peak in the years 2010 and 2011. The data refer to studies done in the states of Pernambuco 5, Rio Grande do Sul 2,6, Minas Gerais 7,8, Rio de Janeiro 9,10,11,12, and São Paulo $13,14,15,16,17$, besides one article that collected data directly from the Ministry of Health in Brasilia 18 . The studies that examined the most lawsuits (between 2,000 and 2,927 cases) were done in the states of São Paulo, Rio de Janeiro, and Santa Catarina $7,12,14,16,19$.

As for the data sources, the majority of the studies analyzed the legal proceedings (83.3\%), and one study only examined the initial lower court rulings 13 , while another examined both initial rulings and the results of appeals 9. The main data sources were: State Health Departments $(41.2 \%)$ and the São Paulo State Online System for Monitoring Legal Proceedings (17.6\%) (Table 2).

Table 3 lists the relevant legal variables presented in the studies. Of all the studies, $64.7 \%$ ( $n=11$ ) specified the form of legal representation for plaintiffs. Six studies 2,9,10,11,14,17 reported a predominance of public legal representation (Office of the Public Defender, Office of the Public Prosecutor, Offices of Municipal, State, and Federal Attorneys). In five studies 6,7,8,16,20, most plaintiffs were represented by private attorneys. In one study, free legal aid was provided to all the plaintiffs 6 . According to two studies, a small number of attorneys and physicians were involved in a large number of lawsuits 7,17. For example, one study found that in one of the law firms representing plaintiffs (165 suits), 43.6\% involved the same physician prescribing adalimumab (for treatment of rheumatoid arthritis), suggesting a possible association between the manufacturing laboratory, prescribers, and attorneys 7 . 




A study in the state of Pernambuco found that in the first half of 2009, the cost of purchasing the medicines in the lawsuits was approximately BRL 4.5 million, and for $70.9 \%$ of the drugs claimed by plaintiffs, the pharmaceutical companies had filed for patents on through the Brazilian National Patent Office (INPI), thus characterizing market control. In addition, $80 \%$ of these drugs were manufactured by eight pharmaceutical companies, and $90.95 \%$ of the funds from the Pernambuco State Health Department (SES-PE) for purchasing these drugs went to just seven laboratories 5 .

Four studies 2,5,6,12 (23,5\%) analyzed the plaintiffs' allegations in the lawsuits, or the grounds for the suit. The main claims involved urgency in the patient's health condition, imminent risk of death, and prescriptions and/or medical and laboratory reports proving the need for the product. In a study in the state of Rio Grande do Sul, $29 \%$ of the lawsuits claimed delay or denial of the drug when requested through normal administrative channels 2 . The fundamental right to health ensured by the Federal Constitution was cited as a justification for claims in at least articles 2,6,12.

Only two studies 6,10 (11.8\%) specified whether the lawsuits were individual or class action, and in two studies the suits were predominantly individual. Three articles 2,6,10 (17.6\%) examined petitions for advance relief or other types of court injunctions, and the results were the following: two studies showed $100 \%$ of such petitions 6,10 and one $98 \% 2$. The majority of the studies $(76.5 \%$; $\mathrm{n}=13$ ) collected specific data to determine whether there was more than one defendant in the suits, four conducted this analysis 2,6,9,10, in two of them the defendants were states and municipalities 9,13 and in the others the defendants were states, municipalities, and the Federal Government 2,6. 
Table 1

Characterization of studies on lawsuits for medicines in Brazil published from 2005 to 2013.

\begin{tabular}{|c|c|c|}
\hline Information on publications & $\mathbf{n}$ & $\%$ \\
\hline \multicolumn{3}{|l|}{ Year of publication } \\
\hline 2013-2012 & 5 & 29.4 \\
\hline $2011-2010$ & 8 & 47.0 \\
\hline 2009-2008 & 2 & 11.8 \\
\hline $2007-2006$ & 1 & 5.9 \\
\hline 2005 & 1 & 5.9 \\
\hline \multicolumn{3}{|l|}{ Scope } \\
\hline Federal Government & 1 & 5.9 \\
\hline São Paulo State & 5 & 29.4 \\
\hline Rio de Janeiro State & 4 & 23.5 \\
\hline Minas Gerais State & 2 & 11.8 \\
\hline Rio Grande do Sul State & 2 & 11.8 \\
\hline Santa Catarina State & 2 & 11.8 \\
\hline Pernambuco State & 1 & 5.9 \\
\hline \multicolumn{3}{|l|}{ Language of publication } \\
\hline Portuguese & 16 & 94.1 \\
\hline English & 1 & 5.9 \\
\hline \multicolumn{3}{|l|}{ Country of publication } \\
\hline Brazil & 16 & 94.1 \\
\hline United States & 1 & 5.9 \\
\hline \multicolumn{3}{|l|}{ Journal } \\
\hline Ciência \& Saúde Coletiva & 2 & 11.8 \\
\hline Revista de Saúde Pública & 8 & 47.0 \\
\hline Cadernos de Saúde Pública & 5 & 29.4 \\
\hline Health and Human Rights & 1 & 5.9 \\
\hline Revista do Direito Sanitário & 1 & 5.9 \\
\hline \multicolumn{3}{|l|}{ Study design } \\
\hline Quantitative/descriptive & 14 & 82.3 \\
\hline $\begin{array}{l}\text { Mixed descriptive (theoretical/ } \\
\text { quantitative) }\end{array}$ & 3 & 17.7 \\
\hline \multicolumn{3}{|l|}{ Number of lawsuits (sample size) } \\
\hline$\leq 500$ & 8 & 47.0 \\
\hline $500-1,000$ & 2 & 11.8 \\
\hline $1,000-1,500$ & 2 & 11.8 \\
\hline $1,500-2,000$ & 0 & 0.0 \\
\hline $2,000-2,500$ & 3 & 17.6 \\
\hline $2,500-3,000$ & 2 & 11.8 \\
\hline
\end{tabular}

\section{Characteristics of the claims examined in the articles}

Table 4 shows the characteristics of the type of drug involved in the claim, type of health care service (public versus private), supply of the drug to the patient, presence of the drug on standard government lists, and registration of the drug in Brazil. Two articles dealt specifically with lawsuits for rare diseases 6,18 , and one focused on claims filed by cancer patients 17 . Of the five studies that examined more than 2,000 lawsuits, only one verified whether the origin of the supply was from the public or private sector, and whether the drugs were registered with the Brazilian National Health Surveillance Agency (ANVISA) 14, and three studies analyzed whether the drugs claimed through lawsuits were part of official government lists 12,14,19. In these same studies with the most lawsuits, one studied a period of more than ten years 7 and the others covered from one to three years $12,14,16,19$. Two of these studies were by the same research group and published analyses from the same sample in different time periods and with different analyses 14,16.

In two studies, the authors used the available data to attempt to classify the plaintiffs based on socioeconomic criteria. In one study, $53 \%$ of the patient-plaintiffs claimed income less than one minimum wage 2 and in another study socioeconomic status was assessed using place of residence as a proxy. In this case, $63 \%$ of the plaintiffs whose addresses were located actually lived in less impoverished areas 18 .

In eight studies, the authors avalyzed the most frequent therapeutic indications. Diabetes mellitus and hypertension led the list ( $\mathrm{n}=5$ and 4 , respectively), followed by chronic obstructive pulmonary disease (COPD), chronic hepatitis C, cancer $(n=3)$, rheumatoid arthritis and kidney disease $(n=2)$. Eleven articles also examined the most frequent drugs in the claims. Insulin glargine was among the most frequent drugs $(n=5)$, followed by adalimumab, etanercept, and infliximab $(n=4)$.

Seven studies examined whether the medicines were registered with the ANVISA, and none of the studies showed more than $5 \%$ of unregistered products. One study examined only two drugs, one of which was registered with ANVISA and the other was not. A study in São Paulo (2010) compared the therapeutic indications claimed in the lawsuits with those in the product registrations. Unapproved indications accounted for $14 \%$ of the claims in 2006 and $10 \%$ in 2007 , based on data from ANVISA, EMEA (European Agency for the Evaluation of Medicinal Products), and the FDA (U.S. Food and Drug Administration). Ten studies specified whether the medicines were on the official lists for pharmaceutical care and the RENAME (the Brazilian National List of Essential Drugs). 
Characterization of types of documents and agencies used as data sources.

\begin{tabular}{lcc}
\hline Data source (type of document and location) & $\mathbf{n}$ & $\%$ \\
\hline Documents & & \\
$\quad$ Preliminary rulings on lawsuits and reports on drug costs & 1 & 5.9 \\
Files on lawsuits for medicines, Ministry of Health & 1 & 5.9 \\
Court proceedings & 14 & 82.3 \\
File on financial authorizations for purchase of drugs & 1 & 5.9 \\
Data collection site & & 11.8 \\
Municipal Health Secretariats * & 2 & 41.2 \\
State Health Secretariats & 7 & 5.9 \\
Ministry of Health, print and electronic files & 1 & 11.8 \\
Website, Court of Justice & 2 & 11.8 \\
Office of the State Attorney (PGE) & 2 & 17.6 \\
System for Registration of Court Proceedings (SCJ) & 3 &
\end{tabular}

* One study also collected data from the Secretariat for Children, Adolescents, Elderly, Family, and Social Development of the Florianopolis Association of Volunteers.

Table 3

Legal variables analyzed by studies on lawsuits for medicines in Brazil.

\begin{tabular}{lcc}
\hline Legal variables & $\mathbf{n}$ & $\%$ \\
\hline Plaintiffs' legal representation (public, private, free legal aid) & 11 & 64.7 \\
Plaintiffs' allegations, and judges' reasons for ruling in favor of claims & 4 & 23.5 \\
Nature of lawsuit (individual or class-action) & 2 & 31.8 \\
Petition for advance relief or other injunctions & 37.6 \\
Defendants (Federal, state, or municipal government or a combination thereof) & 4 & 23.5 \\
\hline
\end{tabular}

\section{Discussion}

The publication of articles on lawsuits for access to medicines has increased significantly in Brazil since 2005, as shown in the data presented in this review. Brazil has four institutions that act to safeguard citizens' rights and compliance with the laws: (1) private attorneys hired by individuals; (2) public advocacy, represented by the Federal, State, and Municipal attorneys, responsible; (3) the Office of the Public Prosecutor, the institution responsible for defending the legal order and overseeing laws; and (4) the Office of the Public Defender, a relatively new institution whose objective is to ensure access to justice for persons with insufficient means 21 .

The lawsuits analyzed in the studies were often filed individually, which raises the issue of distribution of funds in the Brazilian Unified National Health System (SUS), whose principles include universal access and questions concerning whether expenditure of funds to meet an individual claim might lead to lack of funds to supply collective needs 21 . There is no consensus among the parties involved in the judicialization of health, since it involves analyses with different concepts, leading to rulings by judges that generally favor the patient-plaintiff.

One approach used in the studies to identify whether the plaintiffs belong to higher income strata was to analyze their legal representation (public versus private), which in some cases could mean a loss of equity in the health system. Ten studies analyzed the plaintiffs' legal representation $2,6,7,8,9,10,14,16,17,20$, of which three 7,14,16 examined more than two thousand lawsuits, whose plaintiffs were represented predominantly by private attorneys. These studies were done in São Paulo, Rio de Janeiro, and Minas Gerais, states with large populations, and two of the three 
Analysis of articles: most frequent therapeutic indications, drugs most frequently requested, origin of health services, registration with ANVISA, and inclusion on government distribution lists.

\begin{tabular}{|c|c|c|c|c|c|c|}
\hline Authors & Therapeutic indications & $\begin{array}{l}\text { Most frequently requested } \\
\text { drugs }\end{array}$ & $\begin{array}{l}\text { Health } \\
\text { services }\end{array}$ & $\begin{array}{l}\text { \% without } \\
\text { ANVISA } \\
\text { registration }\end{array}$ & $\begin{array}{l}\text { Inclusion on } \\
\text { government } \\
\text { distribution lists }\end{array}$ & $\begin{array}{c}\text { Year of } \\
\text { publication }\end{array}$ \\
\hline $\begin{array}{l}\text { Stamford et al. } 5 \\
(n=105)\end{array}$ & NA & $\begin{array}{l}\text { Antineoplastic drugs and } \\
\text { immune modulators }\end{array}$ & NA & NA & NA & 2012 \\
\hline $\begin{array}{l}\text { Campos Neto et } \\
\text { al. } 7 \\
(n=2,412)\end{array}$ & $\begin{array}{l}\text { Rheumatoid arthritis, type } \\
\text { I diabetes mellitus, chronic } \\
\text { obstructive pulmonary disease, } \\
\text { and ankylosing spondylitis }\end{array}$ & $\begin{array}{c}\text { Adalimumab, etanercept, } \\
\text { ursodeoxycholic acid, } \\
\text { infliximab, and insulin glargine }\end{array}$ & NA & NA & NA & 2012 \\
\hline $\begin{array}{l}\text { Sartoni Junior } \\
\text { et al. } 6 \\
(n=13)\end{array}$ & Fabry's disease * & Alpha-galactosidase ** & Private & $0 \%$ & NA & 2012 \\
\hline $\begin{array}{l}\text { Diniz et al. } 19 \\
(n=196)\end{array}$ &  & Galsulphase ** & NA & NA & NA & 2012 \\
\hline $\begin{array}{l}\text { Biehl et al. }{ }^{2} \\
(n=1,080)\end{array}$ & $\begin{array}{l}\text { Essential hypertension, } \\
\text { diabetes mellitus, chronic } \\
\text { viral hepatitis, ischemic } \\
\text { heart disease, and chronic } \\
\text { obstructive pulmonary disease }\end{array}$ & $\begin{array}{c}\text { Teriparatide, clopidogrel, } \\
\text { insulin glargine, rituximab, } \\
\text { infliximab }\end{array}$ & Public & NA & $\begin{array}{l}\text { Essential drugs } 28 \% ; \\
\text { exceptional drugs } 27 \% \text {; } \\
\text { special drugs } 11 \% ; \\
\text { one strategic action; } \\
56 \% \text { not on list }\end{array}$ & 2012 \\
\hline $\begin{array}{l}\text { Macedo et al. } 13 \\
(n=81)\end{array}$ & NA & NA & NA & NA & $\begin{array}{c}14.3 \% \text { primary care and } \\
19.5 \% \text { exceptional }\end{array}$ & 2011 \\
\hline $\begin{array}{l}\text { Machado et al. } 8 \\
(n=827)\end{array}$ & NA & $\begin{array}{c}\text { Adalimumab, etanercept, } \\
\text { insulin glargine, omeprazole, } \\
\text { aripiprazole }\end{array}$ & Private & $5 \%$ & $\begin{array}{c}\text { 19.6\% on RENAME list; } \\
11.1 \% \text { WHO essential } \\
\text { drugs; } 24.3 \% \text { high-cost; } \\
10.9 \% \text { primary care, } \\
3.5 \% \text { strategic. } 56.7 \% \\
\text { not on list }\end{array}$ & 2011 \\
\hline $\begin{array}{l}\text { Sant }{ }^{\prime} \text { Ana et al. } 9 \\
(n=27)\end{array}$ & NA & $\begin{array}{c}\text { Furosemide; digoxin; } \\
\text { clonazepam; acetyl- } \\
\text { salicylic acid; enalapril and } \\
\text { bromazepam }\end{array}$ & $\begin{array}{l}50 \% \text { private, } \\
50 \% \text { public }\end{array}$ & $0.9 \%$ & $\begin{array}{c}45.2 \% \text { RENAME; } 13.9 \% \\
\text { exceptional }\end{array}$ & 2011 \\
\hline $\begin{array}{l}\text { Borges \& Ugá } 12 \\
(n=2,062)\end{array}$ & NA & NA & NA & NA & $\begin{array}{l}52 \% \text { on Ministry of } \\
\text { Health lists }\end{array}$ & 2010 \\
\hline $\begin{array}{l}\text { Chieffi \& Barata } 16 \\
(n=2,927)\end{array}$ & NA & $\begin{array}{l}\text { Insulin glargine and lispro, } \\
\text { adalimumab, etanercept, } \\
\text { infliximab }\end{array}$ & NA & NA & NA & 2010 \\
\hline $\begin{array}{l}\text { Lopes et al } 17 \\
(n=1,220)\end{array}$ & Cancer\# & $\begin{array}{l}\text { Bevacizumab, capecitabine, } \\
\text { cetuximab, erlotinibe, } \\
\text { imatinibe, rituximab, } \\
\text { temozolomide }\end{array}$ & Private & $\begin{array}{l}\text { 2006: } 14 \% \\
\text { 2007: } 10 \% \# \#\end{array}$ & NA & 2010 \\
\hline $\begin{array}{l}\text { Pepe et al. } 10 \\
(n=185)\end{array}$ & $\begin{array}{l}\text { Hypertension, diabetes } \\
\text { mellitus, degenerative diseases } \\
\text { of the nervous system, chronic } \\
\text { lower airway diseases, and end- } \\
\text { stage renal disease }\end{array}$ & NA & NA & NA & $\begin{array}{l}\text { 35.8\% of drugs on } \\
\text { RENAME list and } \\
\text { 48.1\% on government } \\
\text { distribution lists }\end{array}$ & 2010 \\
\hline
\end{tabular}

(continues) 
Table 4 (continued)

\begin{tabular}{|c|c|c|c|c|c|c|}
\hline Authors & Therapeutic indications & $\begin{array}{c}\text { Most frequently requested } \\
\text { drugs }\end{array}$ & $\begin{array}{l}\text { Health } \\
\text { services }\end{array}$ & $\begin{array}{l}\% \text { without } \\
\text { ANVISA } \\
\text { registration }\end{array}$ & $\begin{array}{l}\text { Inclusion on } \\
\text { government } \\
\text { distribution lists }\end{array}$ & $\begin{array}{c}\text { Year of } \\
\text { publication }\end{array}$ \\
\hline $\begin{array}{l}\text { Pereira et al. } 20 \\
(n=622)\end{array}$ & $\begin{array}{l}\text { Rheumatoid arthritis, } \\
\text { ankylosing spondylitis, psoriatic } \\
\text { arthritis, hepatitis C, ischemic } \\
\text { heart disease, hypertension, } \\
\text { cancer, and diabetes }\end{array}$ & $\begin{array}{c}\text { Infliximab, leflunomide, } \\
\text { etanercept, adalimumab, } \\
\text { propatyl nitrate, clopidogrel, } \\
\text { enalapril,carvedilol, } \\
\text { simvastatin, insulin glargine }\end{array}$ & Private & $1,4 \%$ & $\begin{array}{l}\text { Exceptional/high-cost } \\
\text { drugs } 26.4 \% \text {; primary } \\
\text { pharmaceutical care } \\
2.4 \% \text {; mental health } \\
1.5 \% \text {; strategic } 1.4 \% \text {; } \\
\text { cystic fibrosis } 1 \%\end{array}$ & 2010 \\
\hline $\begin{array}{l}\text { Chieffi \& Barata } 14 \\
(n=2,927)\end{array}$ & NA & NA & Public & $3 \%$ & $\begin{array}{l}23 \% \text { supplied by } \\
\text { SUS,;13\% belonged to } \\
\text { Program for Dispensing } \\
\text { Exceptional Drugs; }\end{array}$ & 2009 \\
\hline $\begin{array}{l}\text { Leite et al. } 18 \\
(n=2,426)\end{array}$ & NA & NA & NA & NA & $\begin{array}{l}32 \% \text { of requested drugs } \\
\text { were part of standard } \\
\text { distribution in the SUS }\end{array}$ & 2009 \\
\hline $\begin{array}{l}\text { Vieira \& Zucchi } 15 \\
(n=170)\end{array}$ & $\begin{array}{l}\text { Diabetes mellitus, cancer, } \\
\text { comorbidities related to } \\
\text { hypertension and diabetes }\end{array}$ & NA & Public & $\begin{array}{l}2 \text { without } \\
\text { registration }\end{array}$ & $\begin{array}{l}\text { 62\% part of REMUME } \\
\text { - São Paulo, or the } \\
\text { list of the Program for } \\
\text { Dispensing Exceptional } \\
\text { Drugs (High-Cost) }\end{array}$ & 2007 \\
\hline $\begin{array}{l}\text { Messeder et al. } 11 \\
(n=389)\end{array}$ & $\begin{array}{l}\text { Until 1998: HIV. } \\
\text { 2000: Crohn's disease, chronic } \\
\text { hepatitis C, and kidney disease } \\
2001 \text { and 2002: essential } \\
\text { hypertension and chronic } \\
\text { ischemic heart disease }\end{array}$ & $\begin{array}{l}\text { 2000: botulin toxin type } \\
\text { A, riluzole and olanzapine. } \\
\text { 2001: cyproterone acetate } \\
\text { and goserelin acetate. } 2002 \text { : } \\
\text { sevelamer hydrochloride and } \\
\text { mesalazine }\end{array}$ & Public & NA & $\begin{array}{c}31.4 \% \text { exceptional, } \\
18.2 \% \text { strategic, } \\
\text { 14/08\% primary care, } \\
19 \% \text { mental health, } \\
3.7 \% \text { state, } 30.8 \% \text { with } \\
\text { no definition of funding }\end{array}$ & 2005 \\
\hline
\end{tabular}

ANVISA: Brazilian National Health Surveillance Agency; n: number of cases and lawsuits analyzed; NA: not analyzed; RENAME: National List of Essential Drugs;

REMUME: Municipal List of Essential Drugs;

* Study limited to patients with Fabry's disease;

** Most frequent;

*** Study limited to briefs from lawsuits on drugs for mucopolysaccharidosis;

\# Study in São Paulo on the seven antineoplastic drugs with the greatest financial impact on the Brazilian Unified National Health System (SUS);

\#\# Analysis based on the therapeutic indications approved by EMEA, FDA, and ANVISA.

studies were by the same authors. An important characteristic of the study in São Paulo is that most of the lawsuits were filed by individuals that were less economically deprived; meanwhile, the drugs claimed in the study in Minas Gerais are among the most costly and most recently available on the Brazilian market. The study identifies an association between the claims and the small number of attorneys and physicians involved in the lawsuits. Despite the high number of lawsuits and the characteristics of the claims, it is difficult to establish a relationship between public versus private legal representation and a conflict with health equity as a common practice in the entire country.
In some states, such as Rio Grande do Sul and São Paulo, in order to receive legal aid from the Office of the Public Defender, there is a limit on the plaintiff's income (three times the minimum wage) 2 , while in other states such as Rio de Janeiro and the Federal District it is necessary to prove insufficient economic means with documents and an affidavit signed by the plaintiff 10 . In this case, one might infer that, in principle, individuals filing claims through the Office of the Public Defender have the lowest socioeconomic status. However, it is not possible to affirm the opposite, since private legal defense is not a good indicator of economic class. The legal costs may often be covered by institutions that have an in- 
terest in judicialization, such as pharmaceutical laboratories and distributors 22 . In addition, such costs would be unaffordable for individuals with very low income, but they would not be an impediment for the majority of the population. An important issue that is discussed among patientplaintiffs is that in states of Brazil that do not have an Office of the Public Defender (or where such an office exists, but with an insufficient number of attorneys), it is possible to hire a private law firm and petition the court for free legal defense. This was reported in at least one study, in which all the patient-plaintiffs received free legal aid 6 . Thus, it cannot be proven that access to medicines via lawsuits in Brazil is mainly for individuals with higher purchasing power.

Four studies analyzed the allegations by patient-plaintiffs, private attorneys or public defenders, and judges to justify the claim for the medicine. The researchers found that the main argument by judges was the fundamental right to health, guaranteed by Article 196 of the 1988 Federal Constitution and Law n. 8,080/1990. According to Stamford \& Cavalcanti 5 , the Constitution has the power to ensure enforcement of public policies. Meanwhile, the allegations by patient-plaintiffs and their attorneys and defenders are based on urgent or emergency need, risk of death, and/or need for the medicine as attested by the physician, and the judges do not generally request any additional information.

Most of the diseases reported in the studies are chronic, such as diabetes mellitus, hypertension, COPD, chronic hepatitis $\mathrm{C}$, ischemic heart disease, and cancer. According to data for 2012 from the International Diabetes Federation, diabetes mellitus affected some 13.4 million adults in Brazil, which represents $6.5 \%$ of the population from 20 to 79 years of age 23 . Another factor to consider in relation to the prevalence of chronic diseases is the change in the population's epidemiological profile related to aging and socioeconomic conditions 14. Data on the therapeutic indications for the medicines were analyzed by nine of the 17 articles included in the review 2,6,7,10,11,15,17,18,20 and show that in most cases the prescribed drugs can be classified as medium to high cost, while four studies were designed to clarify points on rare diseases. Thus, it is not possible to infer that the high cost of lawsuits is due to the lack of organization in primary care. The data in the studies are specific, and are not able to answer this question.

At any rate, the most recent data collected in the studies are from 2011, and some changes may have occurred in the management of pharmaceutical care. Today, drugs that were formally claimed through lawsuits are now covered by the Ministry of Health's budget. Drugs for rheumatoid arthritis (adalimumab, etanercept, and infliximab) 7 are an example of inclusion on the standard drug list of the SUS in 2012. Since 2006 these drugs had already been part of the treatment alternatives listed in clinical protocols and therapeutic guidelines for the disease, which provide for the use of cytokine antagonists as alternative treatment in patients that have failed on other therapies. This time lag is due to the fact that most of the published data are from lawsuits that were tried between 2002 and 2006. No more recently published data on lawsuits were found, while public policies have advanced in Brazil, due largely to the increase in legal claims for medicines.

One limitation to this review is the lack of homogeneity among the studies, since each one focused on a specific aspect of health-related lawsuits, thus hindering a comparative analysis of the articles. The methods adopted in the current review, such as application of descriptors and the criterion of including articles published in indexed journals, may have led to a loss of relevant studies done in different states of Brazil. Another limitation involved quality analysis of the articles with the characteristics of studies on judicialization, requiring the use of STROBE, which is not recommended for backing the analysis for this purpose.

The main limitation to the articles was external validity. The states of Brazil covered in the studies, especially Rio de Janeiro and São Paulo, have populations that are better informed and showed more health-related lawsuits (their populations are presumably more able to identify and claim their rights). Since most of the drugs involved in the claims are medium to high-cost, we believe that the lawsuits contributed to the inclusion of drugs on the current official list for pharmaceutical care, even though the volume of information analyzed and the different research models did not allow a joint analysis of the data. Some characteristics of the lawsuits, such as the fact that the majority of the patient-plaintiffs had chronic diseases and turned to the Office of the Public Defender or private attorneys to access medium to high-cost medicines, do not allow inferences on the management of primary care or a possible breach in health equity. There is a need for further analyses and follow-up on the phenomenon in the health system's management, given that drugs that were not on the Ministry of Health's standard list in 2011 have now been incorporated into the public health system. Evaluation of therapies, elaboration of protocols, and specific proposals for the treatment of rare diseases may prevent the need for 
lawsuits, therebydecreasingthecostofpurchasing these drugs.

Of the selected articles, $25 \%$ reported that at some point in the proceedings there was a petition for advance relief or some other type of injunction, and that in the majority of cases the judges did not request further clarification before granting such requests, but relied only on the medical prescription and the documents presented at the initial hearing. According to the studies, before granting advance relief or injunctions, the courts do not conduct any detailed analysis of the patient's health status, backed by such evidence as laboratory tests, physician's reports, or the urgency of need.

There are first-line therapies for all the most frequent diseases, described in Brazilian and international clinical protocols. The incorporation of new technologies and patient care practices should be based on clinical trials that prove the new drug's safety and efficacy, in addition to costbenefit analysis in relation to existing treatments. Thus, when decisions are made to purchase a given drug without a prior analysis of the treatment alternatives that are already included in the SUS budget, health policy is being overlooked, with potential harm to both the user and the system as a whole. In addition, existing flaws in the organization of the country's pharmaceutical care can lead to shortages in the government pharmacies.

Of the four drugs with the highest demand through lawsuits (insulin glargine, adalimumab, etanercept, and infliximab), the only one not on RENAME for 2013 was insulin glargine, although its use has been standardized in some states, like Minas Gerais 10. Insulin glargine is a longacting insulin analogue. The Brazilian Bulletin on Health Technology Assessment was published in 2010, comparing insulin determir and glargine for the treatment of type I diabetes mellitus, us- ing a literature review of clinical trials on the efficacy and safety outcomes of insulin glargine and detemir, with NPH insulin (neutral protamine Hagedorn).

The clinical evidence and methodological biases identified in the studies do not allow stating whether there is a difference between detemir, glargine, and NPH insulin in terms of glycemic control, and insulin glargine only proved superior in preventing episodes of nocturnal hypoglicemia. A cost-effectiveness study in Canada concluded that replacing NPH insulin with detemir and glargine for the treatment of type I diabetes mellitus would be costly for the national health system 24 .

Ten studies dealt with the issue of funding the drugs and their inclusion on the government lists for free distribution, but it was not possible to group the results, since the studies used different classifications from those of the Ministry of Health. In all the studies that conducted this type of analysis, medicines with free distribution in the public system were requested by lawsuits, especially medicines from the specialized component. The presence of such medicines can be justified since their supply is tied to the Clinical Protocols and Therapeutic Guidelines, and many patients may be using them for offlabel treatment. The presence of the medicines on the RENAME list, when analyzed, varied from $19.6 \%$ to $52 \%$.

Finally, the researchers found that the data were insufficient to establish a socioeconomic profile of the patient-plaintiffs. The lawsuits did not generally contain data on place of birth, schooling, profession, employment, or income, or in some cases even the name of the drug requested or the plaintiff's disease. Many of the researchers identified such lack of information as a major limitation to the studies. 


\section{Resumen}

El objetivo de esta revisión sistemática fue identificar y caracterizar los artículos disponibles en revistas científicas indexadas en bases de datos electrónicas, que llevaron a cabo un estudio cuantitativo de datos, procedi mientos administrativos o judiciales sobre la cuestión del acceso a los medicamentos a través de demandas judiciales. Los estudios fueron localizados en las bases de datos SciELO, LILACS, MEDLINE vía PubMed, Embase, Scopus. Se identificaron 45 artículos, de los cuales se seleccionaron 17. Los estudios que se llevaron a cabo engloban de 2.000 a 2.927 procesos judiciales en São Paulo, Río de Janeiro y Santa Catarina, Brasil. En once estudios se realizaron encuestas a los representantes legales de la acción judicial. En seis estudios predominó la representación pública legal y en cinco abogados privados. Sólo dos estudios examinaron si la acción era individual o colectiva y en los dos hubo prevalencia de acciones individuales. Como la mayoría de los medicamentos estaba involucrada en acciones legales de medio y alto coste, se cree que las demandas han contribuido a la incorporación de fármacos en la política pública actual.

Decisiones Judiciales; Servicios Farmacéuticos; Derecho a la Salud

\section{References}

1. Advocacia Geral da União; Ministério da Saúde Intervenção judicial na saúde pública: panorama no âmbito da Justiça Federal e apontamentos na seara da Justiça Estadual. http://portalsaude. saude.gov.br/portalsaude/arquivos/pdf/2013/ Jun/18/EVOLUcaOGASTOS2.pdf (accessed on 10/ Nov/2013).

2. Biehl J, Amon JJ, Socal MP, Petryna A. Between the court and the clinic: lawsuits for medicines and the right to health in Brazil. Health Hum Rights 2012; 14:1-17.

3. Moher D, Liberati A, Tetzlaff J, Altman DG; PRISMA Group. Preferred reporting items for systematic reviews and meta-analyses: the PRISMA statement. J Clin Epidemiol 2009; 62:1006-12.

4. Malta M, Cardoso LO, Bastos FI, Magnanini MMF, Silva CMFP. Iniciativa STROBE: subsídios para a comunicação de estudos observacionais. Rev Saúde Pública 2010; 44:559-65.

\section{Contributors}

V. S. Gomes and T. A. Amador collaborated in the study planning, data collection, analysis, and interpretation, writing and critical revision of the article, and approval of the final version for publication.

\section{Acknowledgments}

The authors wish to thank Michele Gai for assisting with the article search in the databases.
5. Stamford A, Cavalcanti M. Decisões judiciais para acesso a medicamentos em Pernambuco. Rev Saúde Pública 2012; 46:791-9.

6. Sartoni Junior D, Leivas PGC, Souza MV, Krug BC, Balbinotto G, Schwartz IVD. Judicialização do acesso ao tratamento de doenças genéticas raras: a doença de Fabry no Rio Grande do Sul. Ciênc Saúde Coletiva 2012; 17:2717-28.

7. Campos Neto OH, Acurcio FA, Machado MAA, Ferrá F, Barbosa FLV, Cherchiglia ML, et al. Médicos, advogados e indústria farmacêutica na judicialização da saúde em Minas Gerais, Brasil. Rev Saúde Pública 2012; 46:784-90.

8. Machado MAA, Acurcio FA, Brandão CMR, Faleiros DR, Guerra Jr. AA, Cherchiglia ML, et al. Judicialização do acesso a medicamentos no estado de Minas Gerais, Brasil. Rev Saúde Pública 2011; 45:590-8. 
9. Sant'Ana JMB, Pepe VLE, Figueiredo TA, Osorio-deCastro CGS, Ventura M. Racionalidade terapêutica: elementos médico-sanitários nas demandas judiciais de medicamentos. Rev Saúde Pública 2011; 45:714-21.

10. Pepe VLE, Ventura M, Sant'Ana JMB, Figueiredo TA, Souza VR, Simas L, et al. Caracterização de demandas judiciais de fornecimento de medicamentos "essenciais" no Estado do Rio de Janeiro, Brasil. Cad Saúde Pública 2010; 26:461-71.

11. Messeder AM, Osório-de-Castro CG, Luiza VL. Mandados judiciais como ferramenta para garantia do acesso a medicamentos no setor público: a experiência do Estado do Rio de Janeiro, Brasil. Cad Saúde Pública 2005; 21:525-34.

12. Borges DCL, Ugá MAD. Conflitos e impasses da judicialização na obtenção de medicamentos: as decisões de 1a instância nas ações individuais contra o Estado do Rio de Janeiro, Brasil, em 2005. Cad Saúde Pública 2010; 26:59-69.

13. Macedo EI, Lopes LC, Barberato Filho S. Análise técnica para a tomada de decisão do fornecimento de medicamentos pela via judicial. Rev Saúde Pública 2011; 45:706-13.

14. Chieffi AL, Barata RB. Judicialização da política pública de assistência farmacêutica e equidade. Cad Saúde Pública 2009; 25:1839-49.

15. Vieira FS, Zucchi P. Distorções causadas pelas ações judiciais à política de medicamentos no Brasil. Rev Saúde Pública 2007; 41:214-22.

16. Chieffi AL, Barata RCB. Ações judiciais: estratégia da indústria farmacêutica para introdução de novos medicamentos. Rev Saúde Pública 2010; 44:421-9.

17. Lopes LC, Barberato-Filho S, Costa AC, Osorio-deCastro CGS. Uso racional de medicamentos antineoplásicos e ações judiciais no estado de São Paulo. Rev Saúde Pública 2010; 44:620-8.
18. Leite SN, Pereira SMP, Silva P, Júnior JMN, Cordeiro BC, Veber AP. Ações judiciais e demandas administrativas na garantia do direito de acesso a medicamentos em Florianópolis-SC. Revista do Direito Sanitário 2009; 10:13-28.

19. Diniz D, Medeiros M, Schwartz IVD. Consequências da judicialização das políticas de saúde: custos de medicamentos para as mucopolissacaridoses. Cad Saúde Pública 2012; 28:479-89.

20. Pereira JR, Santos RI, Nascimento Junior JM, Schenkel EP. Análise das demandas judiciais para o fornecimento de medicamentos pela Secretaria de Estado da Saúde de Santa Catarina nos anos de 2003 e 2004. Ciênc Saúde Coletiva 2010; 15: 3551-60.

21. Travassos DV, Ferreira RC, Vargas AMD, Moura RNV, Conceição EMA, Marques DF, et al. Judicialização da saúde: um estudo de caso de três tribunais brasileiros. Ciênc Saúde Coletiva 2013; 18:3419-29.

22. Medeiros M, Diniz D, Schwartz IVD. A tese da judicialização da saúde pelas elites: os medicamentos para mucopolissacaridose. Ciênc Saúde Coletiva 2013; 18:1079-88.

23. International Diabetes Federation. IDF diabetes atlas. http://www.idf.org/sites/default/files/5E_ID FAtlasPoster_2012_EN.pdf (accessed on 20/Dec/ 2013).

24. Insulina Glargina e insulina deternir no controle da diabetes mellitus tip 1. Boletim Brasileiro de Avaliação de Tecnologia em Saúde 2010; Ano V, no 13. http://200.214.130.94/rebrats/brats.php (accessed on 18/Dec/2013).

Submitted on 31/Dec/2013

Final version resubmitted on 02/Oct/2014

Approved on 31/Oct/2014 
Gomes VS, Amador TA. Studies published in indexed journals on lawsuits for medicines in Brazil: a systematic review. Cad Saúde Pública 2015; 31(3):1-12.

http://dx.doi.org/10.1590/0102-311XER010616

The journal has been informed about some errors in the paper. The corrections are follows: A revista foi informada sobre alguns erros no artigo. As correções seguem abaixo:

La revista fue informada sobre algunos errores en el artículo. Siguen las correcciones:

- On page 5, second column, first paragraph, line 10 where the text reads:

....and three studies analyzed whether the drugs claimed through lawsuits were part of official government lists $12,14,19 \ldots$

it should read:

...three studies 12,14,18 analyzed whether the drugs claimed through lawsuits were part of official government lists...

- On page 5, second column, third paragraph, line 29 where the text reads:

...In eight studies, the authors avalyzed the most frequent therapeutic indications. Diabetes mellitus and hypertension led the list ( $n=5$ and 4 , respectively), followed by chronic obstructive pulmonary disease (COPD), chronic hepatitis $C$, cancer $(n=3)$, rheumatoid arthritis and kidney disease $(n=2)$..

it should read:

...In eleven studies 2,6,7,8,9,10,11,15,17,19,20, the authors avalyzed the most frequent therapeutic indications. Diabetes mellitus and hypertension led the list ( $n=6$ and 4 , respectively), followed by chronic obstructive pulmonary disease (COPD), chronic hepatitis $C$, cancer $(n=3)$, rheumatoid arthritis and kidney disease $(n=2) \ldots$

- On page 5, second column, third paragraph, line 35 where the text reads:

...Eleven articles also examined the most frequent drugs in the claims. Insulin glargine was among the most frequent drugs ( $n=5)$, followed by adalimumab, etanercept, and infliximab $(n=4)$..

it should read:

...Twelve articles 2,6,7,8,9,10,11,13,16,17,18,19 also examined the most frequent drugs in the claims. Insulin glargine was among the most frequent drugs $(n=4)$, followed by adalimumab, etanercept, and infliximab $(n=3)$..

- On page 5, second column, fourth paragraph, line 40, where the text reads:

...Seven studies examined whether the medicines were registered with the ANVISA, and none of the studies showed more than $5 \%$ of unregistered products... it should read:

...Eight studies 6,8,9,10,14,15,17,20 examined whether the medicines were registered with the ANVISA, and none of the studies showed more than 5\% of unregistered products..

- On page 5 , second column, fourth paragraph, line 53, where the text reads:

...Ten studies specified whether the medicines were on the official lists for pharmaceutical care and the RENAME (the Brazilian National List of Essential Drugs)..

it should read:

...Eleven studies 2,8,9,10,11,12,13,14,15,18,20 specified whether the medicines were on the official lists for pharmaceutical care and the RENAME (the Brazilian National List of Essential Drugs)...

- $\quad$ On page 9, first column, second paragraph, line 43, where the text reads:

...Data on the therapeutic indications for the medicines were analyzed by nine of the 17 articles included in the review $2,6,7,10,11,15,17,18,20$..

it should read:

...Data on the therapeutic indications for the medicines were analyzed by 12 of the 17 articles included in the review $2,6,7,8,9,10,11,14,15,17,19,20 \ldots$

- On page 10, first column, third paragraph, line 31, where the text reads:

...Of the four drugs with the highest demand through lawsuits (insulin glargine, adalimumab, etanercept, and infliximab), the only one not on RENAME for 2013 was insulin glargine, although its use has been standardized in some states, like Minas Gerais...

it should read:

...Of the five drugs with the highest demand through lawsuits (insulin glargine, adalimumab, etanercept, infliximab and acetyl-salicylic acid), the only one not on RENAME for 2013 was insulin glargine, although its use has been standardized in some states, like Minas Gerais...

- Table 4 in its correct form is: 
Table 4

Analysis of articles: most frequent therapeutic indications, drugs most frequently requested, origin of health services, registration with ANVISA, and inclusion on government distribution lists.

\begin{tabular}{|c|c|c|c|c|c|c|}
\hline Authors & $\begin{array}{l}\text { Therapeutic indications/diag- } \\
\text { nosis * }\end{array}$ & $\begin{array}{c}\text { Most frequently requested } \\
\text { drugs/pharmacological } \\
\text { classes }\end{array}$ & Health services & $\begin{array}{l}\text { \% without } \\
\text { ANVISA } \\
\text { registration }\end{array}$ & $\begin{array}{l}\text { Inclusion on govern- } \\
\text { ment distribution lists }\end{array}$ & $\begin{array}{c}\text { Year of } \\
\text { publica- } \\
\text { tion }\end{array}$ \\
\hline $\begin{array}{l}\text { Stamford et al. } 5 \\
(n=105)\end{array}$ & NA & $\begin{array}{l}\text { Antineoplastic drugs and im- } \\
\text { mune modulators }\end{array}$ & NA & NA & NA & 2012 \\
\hline $\begin{array}{l}\text { Campos Neto et } \\
\text { al. } 7 \\
(n=2,412)\end{array}$ & $\begin{array}{l}\text { Rheumatoid arthritis, type I dia- } \\
\text { betes mellitus, chronic obstruc- } \\
\text { tive pulmonary disease, and } \\
\text { ankylosing spondylitis. }\end{array}$ & $\begin{array}{l}\text { Adalimumab, etanercept, } \\
\text { ursodeoxycholic acid, inflix- } \\
\text { imab, and insulin glargine }\end{array}$ & $\begin{array}{l}87.5 \% \text { private; } \\
12.5 \% \text { public }\end{array}$ & NA & NA & 2012 \\
\hline $\begin{array}{l}\text { Sartoni Junior D } \\
\text { et al. } 6 \\
(n=13)\end{array}$ & Fabry's disease ${ }^{\star \star}$ & 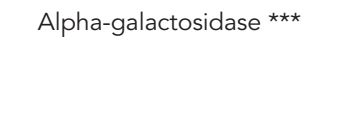 & UH & 0 & NA & 2012 \\
\hline $\begin{array}{l}\text { Diniz et al. } 19 \\
(n=196)\end{array}$ & $\begin{array}{c}\text { Type IV mucopolysaccharido- } \\
\text { sis \# }\end{array}$ & $\begin{array}{c}\text { Galsulphase, idursulphase, } \\
\text { laronidase } * \star \star\end{array}$ & NA & NA & NA & 2012 \\
\hline $\begin{array}{l}\text { Biehl et al. } 2 \\
(n=1,080)\end{array}$ & $\begin{array}{l}\text { Essential hypertension, diabe- } \\
\text { tes mellitus, chronic viral hepa- } \\
\text { titis, ischemic heart disease, } \\
\text { and chronic obstructive pulmo- } \\
\text { nary disease }\end{array}$ & $\begin{array}{l}\text { Budesonide, acetyl-salicylic } \\
\text { acid, formoterol, simvastatin } \\
\text { and hydrochlorothiazide }\end{array}$ & $\begin{array}{l}\text { 45.1\% public; } \\
36.8 \% \text { private; } \\
\text { 14.7\% university } \\
\text { health services; } \\
\quad 3.4 \% \mathrm{WI}\end{array}$ & NA & $\begin{array}{c}\text { Essential drugs } 28 \% ; \\
\text { exceptional drugs } 27 \% ; \\
\text { special drugs } 11 \% \# \#\end{array}$ & 2012 \\
\hline $\begin{array}{l}\text { Macedo et al. } 13 \\
(n=81)\end{array}$ & PI & $\begin{array}{c}\text { Teriparatide, clopidogrel, } \\
\text { insulin glargine, rituximab, } \\
\text { infliximab }\end{array}$ & NA & NA & $\begin{array}{c}14.3 \% \text { primary care and } \\
19.5 \% \text { exceptional }\end{array}$ & 2011 \\
\hline $\begin{array}{l}\text { Machado et al. } 8 \\
(n=827)\end{array}$ & $\begin{array}{l}\text { Rheumatoid arthritis, diabetes } \\
\text { mellitus type I, hypertension, } \\
\text { Schizophrenia and Alzheimer } \\
\text { disease }\end{array}$ & $\begin{array}{l}\text { Adalimumab, etanercept, } \\
\text { insulin glargine, omeprazole, } \\
\text { aripiprazole }\end{array}$ & $\begin{array}{l}70.5 \% \text { private; } \\
25.8 \% \text { public; } 3.7 \% \\
\text { public + private }\end{array}$ & 4.8 & $\begin{array}{c}\text { 19.6\% on RENAME list; } \\
\text { 11.1\% WHO essential } \\
\text { drugs; } 24.3 \% \text { high-cost; } \\
\text { 10.9\% primary care, } \\
3.5 \% \text { strategic. } 56.7 \% \\
\text { not on SHS list }\end{array}$ & 2011 \\
\hline $\begin{array}{l}\text { Sant' Ana et al. } 9 \\
(n=27)\end{array}$ & $\begin{array}{l}\text { Diseases of the circulatory sys- } \\
\text { tem, diseases of the osteomus- } \\
\text { cular system and conjunctive } \\
\text { tissue and mental and behav- } \\
\text { ioral disorders }\end{array}$ & $\begin{array}{l}\text { Furosemide, digoxin; clon- } \\
\text { azepam, acetyl-salicylic acid, } \\
\text { enalapril and bromazepam }\end{array}$ & $\begin{array}{l}50 \% \text { private ( } \pm \\
86.7 \% \text { private doc- } \\
\text { tors and } 13.3 \% \\
\text { health mutualistic } \\
\text { associations); } 50 \% \\
\text { public ( } 40 \% \text { UH } \\
\text { and } 60 \% \text { other } \\
\text { units of SUS) }\end{array}$ & 0.9 & $\begin{array}{c}57.4 \% \text { belonged to } \\
\text { any official list ( } 45.2 \% \\
\text { RENAME; } 32.2 \% \text { other } \\
\text { lists) }\end{array}$ & 2011 \\
\hline $\begin{array}{l}\text { Borges \& Ugá } 12 \\
(n=2,062)\end{array}$ & NA & NA & NA & NA & $\begin{array}{l}52 \% \text { on Brazilian Minis- } \\
\text { try of Health lists; } 48 \% \\
\text { out of the official lists }\end{array}$ & 2010 \\
\hline $\begin{array}{l}\text { Chieffi \& Barata } 16 \\
(n=2,927)\end{array}$ & NA & $\begin{array}{c}\text { Insulin glargine and lispro, } \\
\text { adalimumab, etanercept, } \\
\text { infliximab }\end{array}$ & NA & PI \#\#\# & NA & 2010 \\
\hline $\begin{array}{l}\text { Lopes et al. } 17 \\
(n=1,220)\end{array}$ & Cancer § & $\begin{array}{l}\text { Bevacizumab, capecitabine, } \\
\text { cetuximab, erlotinibe, } \\
\text { imatinibe, rituximab, temo- } \\
\text { zolomide }\end{array}$ & Most private $\S \S$ & $\begin{array}{l}\text { 2006: } 14 \\
\text { 2007: } 10 \S \S\end{array}$ & NA & 2010 \\
\hline
\end{tabular}

(continues) 


\begin{tabular}{|c|c|c|c|c|c|c|}
\hline Authors & $\begin{array}{l}\text { Therapeutic indications/diag- } \\
\text { nosis * }\end{array}$ & $\begin{array}{c}\text { Most frequently requested } \\
\text { drugs/pharmacological } \\
\text { classes }\end{array}$ & Health services & $\begin{array}{l}\% \text { without } \\
\text { ANVISA } \\
\text { registration }\end{array}$ & $\begin{array}{l}\text { Inclusion on govern- } \\
\text { ment distribution lists }\end{array}$ & $\begin{array}{l}\text { Year of } \\
\text { publica- } \\
\text { tion }\end{array}$ \\
\hline $\begin{array}{l}\text { Pepe et al. } 10 \\
(\mathrm{n}=185)\end{array}$ & $\begin{array}{l}\text { Hypertension, diabetes mel- } \\
\text { litus, degenerative diseases of } \\
\text { the nervous system, chronic } \\
\text { lower airway diseases, and } \\
\text { end-stage renal disease }\end{array}$ & $\begin{array}{l}\text { Furosemide, acetyl-salicylic } \\
\text { acid, digoxin, enalapril, } \\
\text { propatilnitrate clonazepam } \\
\text { and captropil }\end{array}$ & NA & NA & $\begin{array}{c}35.8 \% \text { of drugs on } \\
\text { RENAME list and } 48.1 \% \\
\text { on government distribu- } \\
\text { tion lists }\end{array}$ & 2010 \\
\hline $\begin{array}{l}\text { Pereira et al. } 20 \\
(n=622)\end{array}$ & $\begin{array}{l}\text { Rheumatoid arthritis, ankylos- } \\
\text { ing spondylitis, psoriatic arthri- } \\
\text { tis, hepatitis C, ischemic heart } \\
\text { disease, hypertension, cancer, } \\
\text { and diabetes }\end{array}$ & $\mathrm{Pl} \# \#$ & $\begin{array}{l}55.8 \% \text { private; } 33 \% \\
\text { public and } 11.3 \% \\
\text { could not identify }\end{array}$ & 1.4 & $\begin{array}{l}62.2 \% \text { nonstandard; } \\
37.8 \% \text { at any program }\end{array}$ & 2010 \\
\hline $\begin{array}{l}\text { Chieffi \& Barata } 14 \\
(\mathrm{n}=2,927)\end{array}$ & $\mathrm{Pl} \# \#$ & $\begin{array}{l}\text { Therapeutical classes: ali- } \\
\text { mentary tract and metabo- } \\
\text { lism; cardiovascular system; } \\
\text { nervous system }\end{array}$ & $\begin{array}{l}48 \% \text { SUS; } 47 \% \\
\text { complementary } \\
\text { system and } 4 \% \\
\text { could not identify }\end{array}$ & $3 \%(n=954)$ & $\begin{array}{c}77.46 \% \text { out of SUS offi- } \\
\text { cial lists; } 22.54 \% \text { at SUS } \\
\text { official list }\end{array}$ & 2009 \\
\hline $\begin{array}{l}\text { Leite et al. } 18 \\
(n=2,426)\end{array}$ & $\mathrm{Pl} \# \#$ & $\begin{array}{l}\text { Carbamazepine, pimecroli- } \\
\text { mus, "insulines" }\end{array}$ & IP \#\#\# & NA & $\begin{array}{l}32 \% \text { of requested drugs } \\
\text { were part of standard } \\
\text { distribution in the SUS }\end{array}$ & 2009 \\
\hline $\begin{array}{l}\text { Vieira \& Zucchi } 15 \\
(n=170)\end{array}$ & $\begin{array}{c}\text { Diabetes mellitus, cancer, } \\
\text { comorbidities related to hyper- } \\
\text { tension and diabetes }\end{array}$ & $\mathrm{Pl} \# \#$ & $\begin{array}{c}59.2 \% \text { public } \\
\text { (25.8\% municipal; } \\
33.3 \% \text { other) and } \\
40.8 \% \text { private } \\
\text { (13.3\% outsourced } \\
\text { by the SUS, } 27.5 \% \\
\text { no outsourced) }\end{array}$ & $\begin{array}{l}2 \text { without } \\
\text { registration }\end{array}$ & $62 \%$ at SUS official lists & 2007 \\
\hline $\begin{array}{l}\text { Messeder et al. } 11 \\
(n=389)\end{array}$ & $\begin{array}{l}\text { Until 1998: HIV. 2000: Crohn's } \\
\text { disease, chronic hepatitis C, } \\
\text { and kidney disease. } 2001 \text { and } \\
\text { 2002: essential hypertension } \\
\text { and chronic ischemic heart } \\
\text { disease }\end{array}$ & $\begin{array}{l}\text { 2000: botulin toxin type } \\
\text { A, riluzole and olanzapine. } \\
\text { 2001: cyproterone acetate } \\
\text { and goserelin acetate. 2002: } \\
\text { sevelamer hydrochloride and } \\
\text { mesalazine }\end{array}$ & $\begin{array}{c}36.8 \% \mathrm{UH}, 19.5 \% \\
\text { clinics/outsourced } \\
\text { by SUS; } 11.1 \% \mathrm{FH} \text {; } \\
10.5 \% \mathrm{MHS} \text { posts; } \\
10.5 \% \text { private doc- } \\
\text { tors; } 5.5 \% \text { clinics/ } \\
\text { not outsourced } \\
\text { by SUS; } 3.5 \% \mathrm{MH} \text {; } \\
1.3 \% \mathrm{PH} \text { and } 1.3 \% \\
\mathrm{WI}\end{array}$ & NA & $\begin{array}{c}31.4 \% \text { exceptional, } \\
\text { 18.2\% strategic, } 14.0 \% \\
\text { primary care, } 19 \% \text { men- } \\
\text { tal health, } 3.7 \% \text { state, } \\
30.8 \% \text { with no definition } \\
\text { of funding }\end{array}$ & 2005 \\
\hline
\end{tabular}

ANVISA: Brazilian National Health Surveillance Agency; FH: Federal Hospital; MH: Municipal Hospital; MHS: Municipal Health Secretariat; $\mathrm{n}$ : number of cases and lawsuits analyzed; NA: not analyzed; PH: Provincial Hospital; PI: partial information; REMUME: Municipal List of Essential Drugs; RENAME: National List of Essential Drugs; SHS: State Health Secretariat; SUS: Brazilian Unified National Health System; UH: University Hospital; WHO: World Health Organization; WI: without infromation.

*In some studies were presented as "therapeutic indication" and others only "diagnosis" was chosen for the table include the diagnosis as well;

** Study limited to patients with Fabry's disease;

*** Most frequent;

\# Study limited to briefs from lawsuits on drugs for mucopolysaccharidosis;

\#\# Percentage relative to the total of "drugs" on official lists $(n=1,956)$, and 455 have different "drugs" and $56 \%$ of these drugs were outside the official lists; \#\#\# In these cases the data could not be separated for a quantitative analysis, or being presented as "majority" (if the health service, that "most of the SUS prescriptions") or not has been made for \% of the variable in question alone;

$\S$ Study in São Paulo on the seven antineoplastic drugs with the greatest financial impact on the SUS;

$\S \S$ Analysis based on the therapeutic indications approved by EMA, FDA, and ANVISA. 